\title{
Geographic risk factors for inter-river dispersal of Gyrodactylus salaris in fjord systems in Norway
}

\author{
Peder A. Jansen ${ }^{1, *}$, Louise Matthews ${ }^{2}$, Nils Toft $^{3}$ \\ ${ }^{1}$ Section of Epidemiology, National Veterinary Institute, PO Box 8156 Dep, 0033 Oslo, Norway \\ ${ }^{2}$ Institute for Comparative Medicine, Faculty of Veterinary Medicine, University of Glasgow, Bearsden Road, \\ Glasgow G61 1QH, UK \\ ${ }^{3}$ Department of Large Animal Sciences, The Royal Veterinary and Agricultural University, Grønnegårdsvej 8, \\ 1870 Frederiksberg C, Denmark
}

\begin{abstract}
Gyrodactylus salaris has been recorded in 46 Norwegian rivers since 1975 and is considered a threat to Atlantic salmon stocks. The primary introductions of G. salaris (primary infected rivers) have been accounted for by specific events, as reported in the literature. The parasite has subsequently dispersed to adjacent localities (secondary infected rivers). The objective of this paper is to address the occurrence of secondary infections by examining the hypothesis of inter-river dispersal of G. salaris. A dispersal model for the secondary river infections via migrating infected fish is proposed. Due to the limited tolerance of G. salaris to salinity, both freshwater inflow to dispersal pathways and dispersal distance were expected to influence the probability of inter-river dispersal. Eighteen rivers were categorised as primary infected rivers, 28 as secondary infected rivers, and 54 as rivers at risk. Four risk factors: the $\log _{10}$ freshwater inflow; the dispersal distance; the time at risk; and the salmon harvest were combined in a multi-variable logistic regression model of the probability of secondary infection. The final multi-variable model included $\log _{10}$ freshwater inflow (Wald chisquare $=9.93$ ) and dispersal distance (Wald chi-square $=6.48$ ). Receiver operating characteristic analyses of the final model supported freshwater inflow as a strong predictor of G. salaris infection status. The strong influence of the freshwater inflow on the probability of secondary infection adds further support to the hypothesis of inter-river dispersal of G. salaris through fjords.
\end{abstract}

KEY WORDS: Gyrodactylus salaries $\cdot$ Atlantic salmon · Dispersal model $\cdot$ Fjord systems Resale or republication not permitted without written consent of the publisher

\section{INTRODUCTION}

Gyrodactylus salaris is a monogenean ectoparasitic worm that reproduces directly on the host. The parasite possesses no specific transmission stage or swimming ability (Bakke et al. 1992, Soleng et al. 1999, Olstad et al. 2006). Gyrodactylids are considered host specific, but $G$. salaris has been recorded in a relatively wide range of hosts (Harris et al. 2004). However, under natural conditions, the parasite is only known to be pathogenic to Atlantic salmon (Bakke et al. 1992). G. salaris fecundity, longevity and transmission rates are influenced by water temperature (Jansen \& Bakke 1991, Soleng et al. 1999, Cable et al. 2000). Addition- ally, the parasite is known to have limited tolerance to salt water (Soleng \& Bakke 1997).

The first record of Gyrodactylus salaris in Norway was at a fish farm at Sunndalsøra, Møre and Romsdal County, in 1975 (Mo \& Nordheim 2005). Later the same year the parasite was recorded for the first time infecting juvenile Atlantic salmon in a river in Nordland County (Johnsen 1978). G. salaris has since been recorded from an additional 45 Norwegian rivers and the parasite is considered to be a major threat to natural Atlantic salmon stocks in Norway (Anonymous 1999). It is now a widely accepted theory that $G$. salaris was introduced to Norway sometime in the early 1970s and spread through anthropogenic stocking of rivers 
with infected hatchery-reared juvenile salmon (Johnsen \& Jensen 1986, Bakke et al. 1990, Hansen et al. 2003).

Characteristic of Gyrodactylus salaris infection in Norwegian rivers is the parasite's capacity to propagate epidemics in pre-smolt Atlantic salmon. When introduced to a new salmon river, the parasite spreads throughout the juvenile salmon population within a few years, with prevalences approaching 100\% and individual salmon often carrying thousands of parasites (Johnsen \& Jensen 1991, Jansen \& Bakke 1993, Appleby \& Mo 1997). This has caused dramatic declines, or near extermination, of infected salmon populations (Johnsen \& Jensen 1991, Johnsen et al. 1999). Due to the economic impact of the parasite, surveillance activities in rivers without known G. salaris infection are extensive. Since 2001, a national surveillance program for $G$. salaris has been coordinated by the National Veterinary Institute (NVI) in Norway. Between 2001 and 2005 an average of 121 rivers were surveyed for G. salaris per year (Mo \& Nordheim 2002, 2003, 2004, 2005, 2006).

Johnsen \& Jensen (1986) outlined the surveillance initiated by the 'Gyrodactylus committee', in the early 1980s. The authors established close agreement between G. salaris-infected regions and accounts of fish delivered for river stocking from G. salaris-infected hatcheries. This association has been explored in greater detail in Halvorsen \& Hartvigsen (1989), Johnsen \& Jensen (1991) and Johnsen et al. (1999), and it is evident that most of the early dissemination of $G$. salaris in Norway can be traced back to the Sunndalsøra fish farm, where the parasite was first recorded. Additionally, Johnsen \& Jensen (1986) introduced the hypothesis that $G$. salaris disperses between rivers on fish migrating through brackish water in fjords. Outlets of infected rivers into fjords were found to be located sufficiently close to each other that this seemed a plausible proposition. Circumstantial evidence supporting this hypothesis has subsequently appeared: (1) the salinity tolerance of G. salaris (Soleng \& Bakke 1997); (2) records of $G$. salaris infection in salmon smolts in brackish water (Soleng et al. 1998); (3) juvenile salmon migration in fjords (Lund \& Heggberget 1992, Finstad et al. 2005); and (4) risk assessment models (Høgåsen \& Brun 2003). Johnsen \& Jensen (1991), Soleng et al. (1998) and Høgåsen \& Brun (2003) all give accounts of the mechanisms by which inter-river dispersal of $G$. salaris on fish migrating through brackish water in fjords may occur.

Norwegian management policy aims to control and eliminate Gyrodactylus salaris, for instance by killing entire river populations of fish with the pesticide rotenone (Johnsen \& Jensen 1991), or more recently by the use of aqueous aluminium that aims to target and eradicate the parasite populations specifically (Poleo et al. 2004). To prevent further dispersal of G. salaris, it is therefore important to know the circumstances under which the parasite disperses to neighbouring rivers. Given the parasite's limited salinity tolerance, the amount of freshwater inflow into a fjord system should influence the probability of inter-river dispersal of $G$. salaris within the system. Similarly, the distance between river outlets should be of importance since short distances could permit a shorter duration of dispersal through a hostile environment for the parasite. The time at risk and the salmon density could also potentially influence inter-river dispersal. The objective of the present study was to assess the hypothesis of interriver dispersal of $G$. salaris in fjord systems in Norway by modelling the inter-river dispersal as a function of the above potential risk factors.

\section{MATERIALS AND METHODS}

Identifying infected rivers and regions. Johnsen \& Jensen $(1985,1986,1991)$ and Johnsen et al. (1999) reviewed information concerning the possible origin of Gyrodactylus salaris in Norwegian rivers up to the year 2000. In the present study we used Johnsen et al. (1999) to identify 40 G. salaris-infected rivers and the year of the first $G$. salaris record in these rivers, up to the year 2000. In the period 2000 to 2006 G. salaris was recorded in 6 new rivers: one in Troms County in 2000; 1 in Nord-Trøndelag County in 2001; 2 in Nordland County in 2002; 1 in Vestfold County in 2003; and 1 in Nordland County in 2006. Thus, G. salaris has been recorded, to date, in a total of 46 rivers in Norway (Mo \& Nordheim 2002, 2003, 2004, T. A. Mo, NVI, pers. comm.). The infected rivers were assigned to regions bounded by fjord systems into which they drain, from Region 1 (R1) in the southeast to Region 12 (R12) in the north of Norway (Fig. 1).

Primary infected rivers. A total of 18 rivers were categorised as primary infected rivers. According to Johnsen \& Jensen (1985) and Johnsen et al. (1999), 9 primary infected rivers received juvenile salmon for stock enhancement purposes from the originally infected fish farm at Sunndalsøra. Another 6 primary infected rivers were associated with fish farms, through water supply or water outlet in the rivers, either from which Gyrodactylus salaris was diagnosed (4 farms) or where documentation exists with regard to imports of live salmon from known infected fish farms such as the Sunndalsøra farm or the fish farm at Hölle, Sweden (Malmberg 1988, Johnsen et al. 1999). In the primary infected River Skibotnelva (R12) documentation exists of a fish transport coming from a known $G$. salaris endemic area in Sweden. This transport appar- 


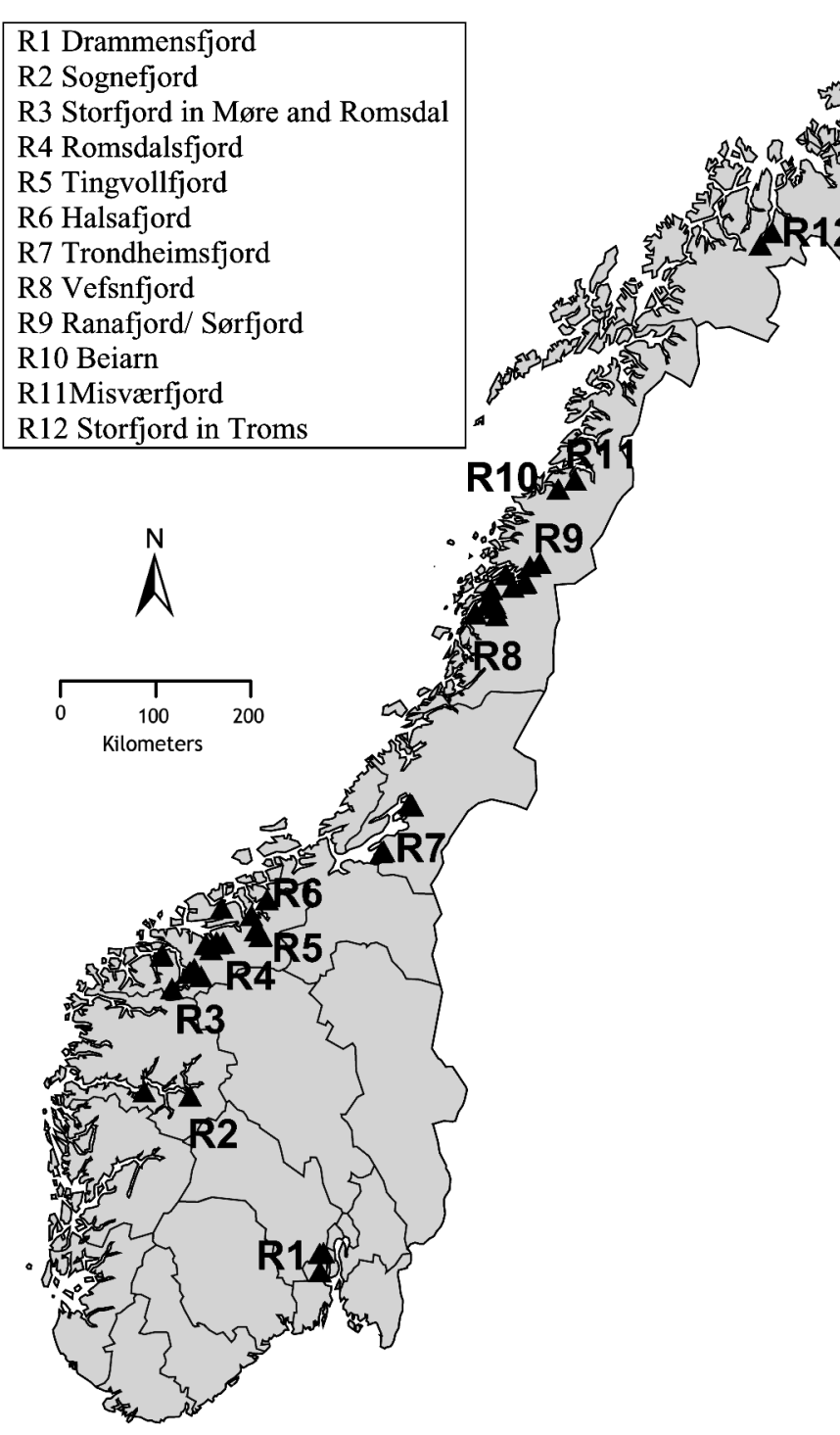

ently dumped Atlantic salmon smolts and waste water into the river (Johnsen \& Jensen 1986, Johnsen et al. 1999). The origin of G. salaris in the remaining 2 rivers designated as primary infected rivers, the Rivers Beiarn and Lærdalselva, is unknown. These rivers do not share a common fjord system with other infected rivers that could have been a source of infection. The primary infected River Vikja in the same region as the River Lærdalselva had been treated with rotenone in 1982, 15 yr prior to records of the parasite in the River Lærdalselva. The parasite has not been recorded in the River Vikja following the 1982 treatment despite extensive surveillance of juvenile salmon (Johnsen et al. 1999).

Secondary infected rivers. A total of 28 infected rivers were categorised as secondary infected rivers. The secondary infected rivers all share a fjord system
Fig. 1. Forty-six rivers (\) from which Gyrodactylus salaris have been recorded in Norway. Rivers are assigned to regions (R1-R12) bounded by fjord systems (see key) into which the rivers drain with at least one primary infected river. Dispersal through fjord systems has been suggested (Johnsen \& Jensen 1986) as the origin of Gyrodactylus salaris in the secondary infected rivers (Fig. 2) with no wellsupported alternative hypotheses. One exception to this may be the River Litledalselva, where Johnsen et al. (1999) suggested a possible route of infection directly from the Sunndalsøra fish farm. However, changing the categorisation of this river does not substantially affect the results since the distance to the outlet of the River Driva was short and the inflow of freshwater high in this area (Fig. 2).

Rivers at risk. Salmon rivers with no record of Gyrodactylus salaris infection which drain into seawater in the same regions as G. salaris-infected rivers were identified from a database supported by the Directorate for Nature Management (www.dirnat.no). This database evaluates and ranks the environmental state of anadromous salmonid stocks in 1265 rivers in Norway, and provides geographical coordinates of the river outlets into seawater. A total of 54 rivers with an evaluated status for Atlantic salmon stocks were identified from the database. Rivers in which the state of the Atlantic salmon stocks are unknown, or rivers in which the stocks are considered to be threatened by extinction (i.e. a rank of 2 or less in the database), were rejected (Fig. 2).

Dispersal pathways. We assumed that the most likely dispersal pathway for Gyrodactylus salaris to a given river would be fjord-wise from the nearest infected river. It was assumed that there has been inter-river dispersal of G. salaris infection from primary infected rivers to secondary infected rivers, and further dispersal between secondary infected rivers. Non-infected rivers were assumed to have been at risk of acquiring infection. Hence, for each of the 28 secondary infected and 54 rivers at risk in the study, one specific G. salaris source river was postulated. Source rivers were identified as the G. salaris-infected rivers with the shortest fjord-wise path from their outlet to the outlet of the given rivers in the model. For secondary infected rivers an additional requirement was that $G$. salaris had been recorded in the source river prior to, or $1 \mathrm{yr}$ post, the first record of $G$. salaris in the given secondary infected river. The reason for allowing the infection process to 


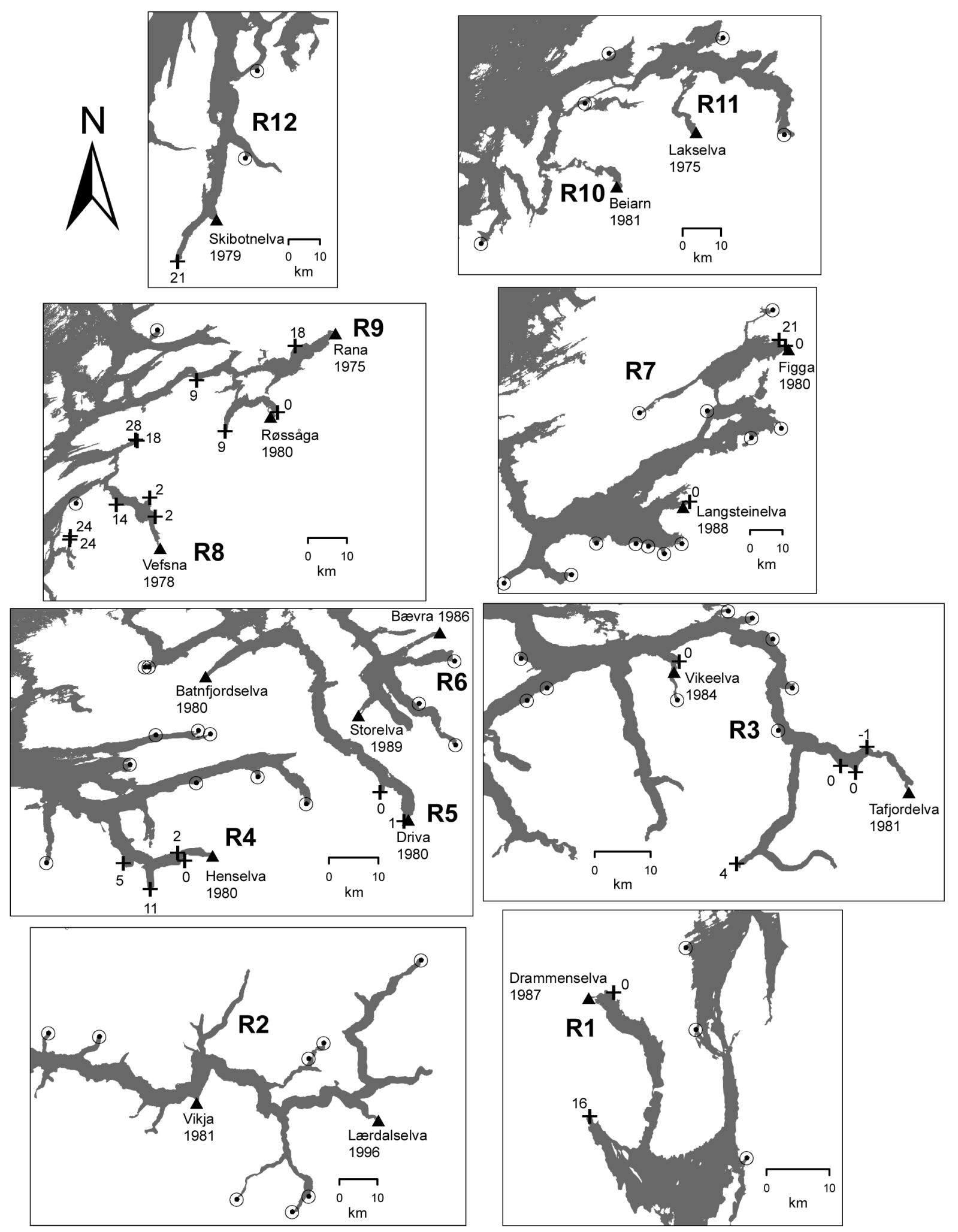

Fig. 2. Primary $(\boldsymbol{\Delta})$ and secondary (+) infected rivers, and rivers at risk $(\bullet)$ in different regions (see Fig. 1). Primary infected rivers are labelled with names and the year of the first Gyrodactylus salaris record. Secondary infected rivers are labelled with the time-period (yr) between the first record of Gyrodactylus salaris in the nearest primary infected river and the first record in the given labelled river 
move 1 yr 'backwards' in time (in one instance from the primary infected river in Region 3, R3, Fig. 2) was to account for a possible discrepancy between rivers in the delay between the first $G$. salaris record and the actual $G$. salaris introduction time to rivers.

Dispersal distance. Due to the restricted survival of Gyrodactylus salaris in saline water (Soleng \& Bakke 1997), and the proposed mode of inter-river dispersal via migrating infected fish in fjords (Johnsen \& Jensen 1986), distances between river outlets and salinity in the fjord locations covering these distances were assumed to be risk factors for G. salaris dispersal. Dispersal distance $(\mathrm{km})$ was measured as the shortest fjord-wise path from the outlet of a source river to the outlet of a given secondary infected river or river at risk using digital maps (N250) from Statens Kartverk (www.statkart.no) and the distance measuring tool in ArcMap version 9.0 (ESRI).

Freshwater inflow. Salinity in fjords varies temporally due to climatic conditions and with the volume of freshwater that drains into them. Since salinity records in Norwegian fjords are fragmentary both in space and time, we generated a proxy variable expressing the relative volume of freshwater inflow into fjord areas covering the postulated dispersal pathways for Gyrodactylus salaris. Freshwater inflow to the fjords was derived from the database Regine which is supported by the Norwegian Water Resources and Energy Directorate (www.nve.no). The Regine database quotes mean annual water inflow into the sea (million $\mathrm{m}^{3} \mathrm{yr}^{-1}$ ) over a period of $40 \mathrm{yr}$ (1961 to 1999) from the given rivers. These data are accessible at http://arcus.nve. no/website/nve/viewer.htm. To generate a variable accounting for freshwater inflow to dispersal pathways, all secondary infected rivers and rivers at risk were assigned to the closest primary infected river. For all primary infected rivers, a raster layer of fjord-wise distances from the outlet was computed using the costweighted distance tool in the ArcView extension Spatial Analyst (ESRI), with $10^{4} \mathrm{~m}^{2}$ grid cells. A raster layer covering the Norwegian coast $\left(10^{4} \mathrm{~m}^{2}\right.$ grid cells) was used as the cost raster in the Spatial Analyst procedure. To derive a relative inflow of freshwater for the postulated dispersal pathway to a given river, first the area of a given fjord within distances less than or equal to the distance between the given river outlet and the outlet of the assigned primary infected river was recorded. This area was calculated as the number of grid cells in the fjord-wise distance raster layer with values less than or equal to the distance value of the grid cell covering the given river outlet. Second, all inflow of freshwater from rivers in the Regine database covered by the recorded area was summarised and divided by area. This procedure was repeated for successive secondary infected rivers and rivers at risk at increasing distances from the respective outlets of assigned primary infected rivers. Thus we obtained, for each river, the mean annual freshwater inflow per area of fjord covering the postulated dispersal pathways. This variable has the dimension $100 \mathrm{~m}^{3}$ freshwater $\mathrm{m}^{-2}$ fjord area $\mathrm{yr}^{-1}$ and is hereafter termed freshwater inflow.

Salmon harvest in source rivers. The number of juvenile salmon migrating from an infected source river may increase the infection pressure on neighbouring rivers. A categorical variable accounting for gross yearly harvests of Atlantic salmon for the Gyrodactylus salaris source rivers was compiled to approximate juvenile salmon migration. Three harvest categories covered yearly catches of (1) $<500 \mathrm{~kg}$, (2) 500 to $5000 \mathrm{~kg}$ and (3) $>5000 \mathrm{~kg}$. Harvest categories for source rivers were determined from the mean of the 3 highest yearly catches reported for the respective rivers in Johnsen et al. (1999).

Time at risk. For each river, an ordinal variable accounting for the time period that rivers could have been at risk of being infected with Gyrodactylus salaris was constructed. The time periods assigned to secondary infected rivers and rivers at risk were the number of years from the first observation of the parasite in the closest primary infected river to either 2006 or the time at which rotenone treatments eradicated the parasite (Johnsen et al. 1999). Time periods at risk were categorized in (1) <10 yr, (2) 10-20 yr and (3) > $20 \mathrm{yr}$.

Statistical analysis. Descriptive statistical analyses were performed for each of the potential risk factors for Gyrodactylus salaris infection status, i.e. secondary infected rivers vs. rivers at risk. The potential association between risk factor and infection status was evaluated using Fisher's exact test for categorical data and $t$-test for continuous data.

To evaluate the association between the probability of inter-river dispersal of Gyrodactylus salaris and the potential risk factors in a multi-variable analysis, we used logistic regression:

$$
\operatorname{logit}\left(\mathrm{p}_{i}\right)=\alpha+\sum \beta_{i} \mathrm{X}_{i}
$$

where $\mathrm{p}_{i}$ is the probability of the $i$ th river being infected with $G$. salaris; $\alpha$ is the intercept term; $\beta_{i}$ is the vector of regression parameters; and $\mathrm{X}_{i}$ is the vector of covariates for the ith river. Relative freshwater inflow was $\log _{10}$ transformed to improve the assumption of a linear association on the logit scale. Risk factors were added to the model by forward selection, i.e. risk factors were added in the order of their statistical influence as determined by Wald chisquare until no risk factors or 2-way interactions met the inclusion criteria of a p-value $\leq 0.05$. The goodness-of-fit of the final model was assessed by the Hosmer and Lemeshow Test. The predictive ability of 
the final dispersal model was assessed by receiver operating characteristic curves (ROC) and the associated area under the curve (AUC). Statistical analyses were conducted using SAS Enterprise Guide 3.0. (SAS Institute).

\section{RESULTS}

Rivers in which Gyrodactylus salaris has been recorded are located from Troms County in the North to Buskerud County in the southeast, with the most affected counties being Møre and Romsdal, and Nordland (Fig. 1). Fjord systems form natural boundaries for 12 regions that have experienced G. salaris infection in Norway (Fig. 2). Secondary infected rivers were identified in 8 of the regions.

Descriptive statistics for the 4 potential risk factors are given in Table 1. Only source river harvest was not significantly associated with infection status (Fisher's Exact, p-value $=0.86$ ) . Time period at risk was longer for secondary infected rivers compared to rivers at risk (Fisher's Exact, $\mathrm{p}=0.0005$ ). The mean

Table 1. Descriptive statistics for the potential risk factors for inter-river dispersal of secondary Gyrodactylus salaris infection in Norwegian rivers

\begin{tabular}{|c|c|c|c|c|}
\hline Variable & Level & $\begin{array}{l}\text { Rivers } \\
\text { at risk }\end{array}$ & $\begin{array}{c}\text { Secondary } \\
\text { infected rivers }\end{array}$ & $\begin{array}{l}\mathrm{p} \text {-value for } \\
\text { association }\end{array}$ \\
\hline $\begin{array}{l}\log _{10} \text { relative freshwater } \\
\text { inflow }\left(100 \mathrm{~m}^{3} \text { fresh- }\right. \\
\left.\text { water } \mathrm{m}^{-2} \text { fjord area } \mathrm{yr}^{-1}\right)\end{array}$ & $\begin{array}{c}\text { Mean } \\
(95 \% \mathrm{CI}) \\
\mathrm{SD}\end{array}$ & $\begin{array}{c}-1.04 \\
(-1.15 ;-0.93) \\
0.41\end{array}$ & $\begin{array}{c}-0.02 \\
(-0.27 ; 0.22) \\
0.63\end{array}$ & $<0.0001$ \\
\hline Dispersal distance $(\mathrm{km})$ & $\begin{array}{c}\text { Mean } \\
(95 \% \mathrm{CI}) \\
\mathrm{SD}\end{array}$ & $\begin{array}{c}36.1 \\
(32.0 ; 40.1) \\
14.9\end{array}$ & $\begin{array}{c}11.3 \\
(6.9 ; 15.6) \\
11.2\end{array}$ & $<0.0001$ \\
\hline $\begin{array}{l}\text { Salmon harvest in source } \\
\text { rivers }\left(\mathrm{kg} \mathrm{yr}^{-1}\right)\end{array}$ & $\begin{array}{l}<500 \\
500-5000 \\
>500\end{array}$ & $\begin{array}{c}19 \\
28 \\
7\end{array}$ & $\begin{array}{c}10 \\
13 \\
5\end{array}$ & 0.86 \\
\hline Time at risk (yr) & $\begin{array}{c}<10 \\
10-20 \\
>20\end{array}$ & $\begin{array}{l}25 \\
10 \\
19\end{array}$ & $\begin{array}{c}2 \\
6 \\
20\end{array}$ & 0.0005 \\
\hline
\end{tabular}

Table 2. Estimates for the logistic regression and the association of dispersal distance $(\mathrm{km})$ and $\log _{10}$ relative freshwater inflow $\left(100 \mathrm{~m}^{3}\right.$ freshwater $\mathrm{m}^{-2}$ fjord area $\left.\mathrm{yr}^{-1}\right)$, for the postulated dispersal pathway, with the probability of secondary Gyrodactylus salaris infection in Norwegian rivers. $\mathrm{n}=28$ secondary infected rivers; 54 rivers at risk. Model Pearsons chi-square $=50.01 ; \mathrm{df}=2 ; \mathrm{R}^{2}=0.55\left(\right.$ max-rescaled $\left.\mathrm{R}^{2}=0.77\right)$; $\mathrm{p}<0.0001$

\begin{tabular}{|lrccr|}
\hline Parameter & Estimate & $\begin{array}{c}\text { Wald } \\
\text { chi-square }\end{array}$ & $\begin{array}{c}\text { Wald } \\
95 \% \text { CI }\end{array}$ & $p$ \\
\hline Intercept $(\alpha)$ & 3.779 & 13.21 & $(1.741 ; 5.817)$ & $<0.001$ \\
Dispersal distance & -0.082 & 6.48 & $(-0.146 ;-0.019)$ & 0.011 \\
Log $_{10}$ freshwater inflow & 3.923 & 9.93 & $(1.483 ; 6.364)$ & 0.002 \\
\hline
\end{tabular}

$\log _{10}$ freshwater inflow $\left(100 \mathrm{~m}^{3}\right.$ freshwater $\mathrm{m}^{-2}$ fjord area $\mathrm{yr}^{-1}$ ) was significantly higher, and the mean dispersal distance $(\mathrm{km})$ significantly shorter, for secondary infected rivers compared to rivers at risk ( $t$-test with Satterthwaite method for unequal variance, $\mathrm{p}<0.0001$ for both).

The forward selection of risk factors in the logistic regression dispersal model included $\log _{10}$ freshwater inflow (Wald chi-square $=9.93$ ) followed by dispersal stance (Wald chi-square $=6.48$ ). No other variables infection in rivers is provided in Appendix 1.

The farthest dispersal distance postulated in the regression model was $38.7 \mathrm{~km}$ between the outlets of the Rivers Drammenselva and Sandeelva (R1). For low and high values of $\log _{10}$ freshwater inflow, corresponding to values equal to -1.36 (the 10th percentile) and 0.23 (the 90th percentile), the predicted probabilities of Gyrodactylus salaris infection were 0.13 to 0.002 and 0.99 to 0.56 for dispersal distances of 4 and $54 \mathrm{~km} \mathrm{(10} \mathrm{and}$ 90th percentiles for dispersal distance). For $\log _{10}$ freshwater inflow equal to -0.69 (the mean value), the corresponding predicted probabilities of $G$. salaris infection in rivers were $0.56,0.36$ and 0.20 for dispersal distances of 10, 20 and $30 \mathrm{~km}$, respectively (Fig. 3). The combined effect of $\log _{10}$ freshwater inflow and dispersal distance in the logistic regression model explained up to $77 \%$ (max-rescaled $\mathrm{R}^{2}=0.77$ ) of the variation in the data, i.e. in the probabilities of $G$. salaris infection. The predictive ability of the model was further assessed using ROC curves (Fig. 4). The AUC (a measure of discrimination) was 0.97 , indicating a high ability to correctly classify secondary infected rivers and rivers at risk. The 2-graph ROC curve allows the effect of changing the cutoff point to be visually assessed. For comparison, the AUC for a dispersal model with only $\log _{10}$ freshwater inflow was 0.94 . 


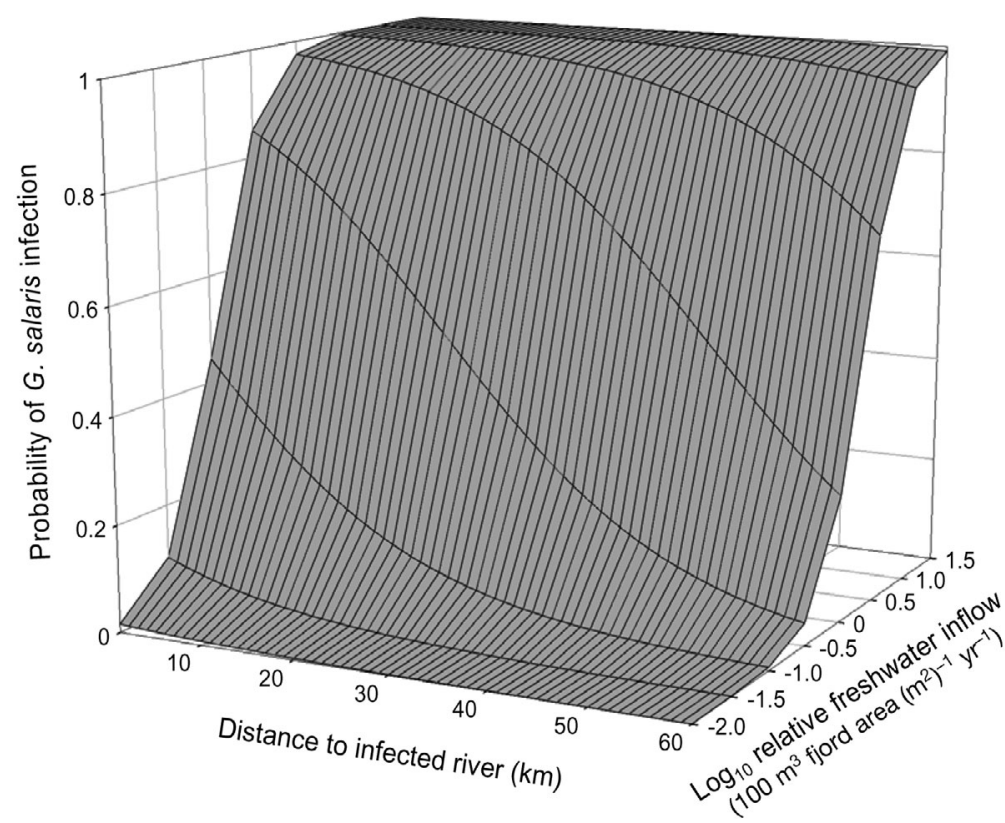

Fig. 3. Predicted probability of Gyrodactylus salaris infection in rivers as a function of $\log _{10}$ freshwater inflow $\left(100 \mathrm{~m}^{3}\right.$ freshwater $\mathrm{m}^{-2}$ fjord area $\mathrm{yr}^{-1}$ ) and dispersal distance $(\mathrm{km})$. Probabilities were derived from the parameter estimates in Table 2
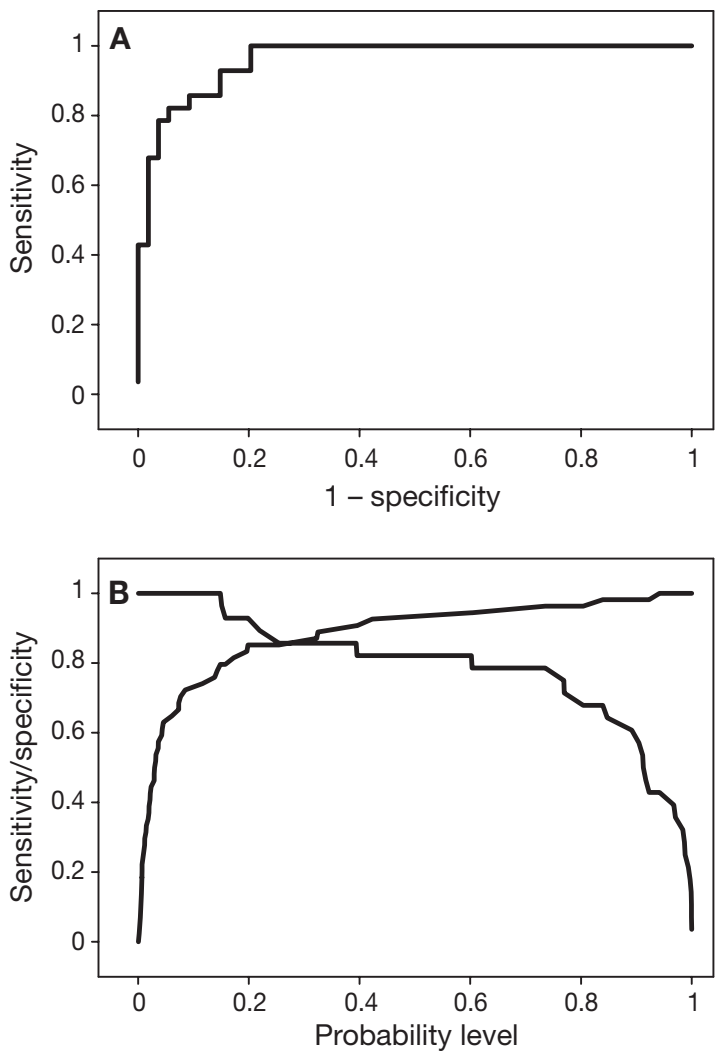

Fig. 4. (A) Receiver operating characteristic (ROC) curve and (B) the 2-graph ROC for the dispersal model with $\log _{10}$ freshwater inflow $\left(100 \mathrm{~m}^{3}\right.$ freshwater $\mathrm{m}^{-2}$ fjord area $\left.\mathrm{yr}^{-1}\right)$ and dispersal distance $(\mathrm{km})$. Area under the ROC curve is 0.97

\section{DISCUSSION}

This study has shown that freshwater inflow and fjord-wise distance to the nearest Gyrodactylus salaris-infected river are important risk factors for infection in secondary infected rivers. Especially freshwater inflow was a strong predictor of G. salaris infection status. The longest dispersal distance through a fjord postulated in the present model was close to $40 \mathrm{~km}$, but in most cases these distances were less than $10 \mathrm{~km}$. This is in accordance with the predictions arising from the hypothesis of inter-river dispersal of G. salaris in fjord systems in Norway (Johnsen \& Jensen 1986, Soleng \& Bakke 1997, Soleng et al. 1998).

The reasoning behind Johnsen \& Jensen's (1986) hypothesis of inter-river dispersal of Gyrodactylus salaris was the close proximity between the outlets of infected rivers, which is particularly evident in Regions 3, 4 and 8 (see Fig. 2). In theory, this clustering of infected rivers could be due to other routes of transmission (Peeler et al. 2004). However, a large body of circumstantial evidence has built up to support the hypothesis of interriver dispersal of $G$. salaris through fjord systems. Studies have shown Atlantic salmon parr to migrate a minimum distance of $2.7 \mathrm{~km}$ in a Norwegian fjord, and hatchery reared Atlantic salmon smolts to migrate distances of 48 and $77 \mathrm{~km}$ in a fjord after 65 and $83 \mathrm{~h}$, respectively (Lund \& Heggberget 1992, Finstad et al. 2005). G. salaris was recorded on experimental fish after more than $200 \mathrm{~h}$ at $10 \%$ salinity and $72 \mathrm{~h}$ at $15 \%$ o salinity, and 37 out of 52 Atlantic salmon smolts caught $25 \mathrm{~km}$ from the outlet of the River Drammenselva were infected with up to 1105 G. salaris specimens (Soleng \& Bakke 1997, Soleng et al. 1998). Risk assessment studies of fjord-wise dispersal pathways to salmon rivers near to the River Drammenselva estimated an annual risk of $31 \%$ for the event that at least one infected salmon smolt would enter the River Sandeelva (Høgåsen \& Brun 2003). G. salaris readily transmits to a wide range of both salmonid and non-salmonid host species, suggesting that a range of species may serve as short-term transport hosts for the parasite (Bakke et al. 2002). Additional support for the hypothesis of interriver dispersal of $G$. salaris through fjord systems comes from experience with re-infection of rivers after rotenone treatments that have failed to completely eradicate the parasite. In Region 4, all rivers known to be G. salaris infected were treated in 1993. In 1996 G. salaris was recorded again in the River Rauma, the largest river in the region. Later G. salaris was recovered from the Rivers Innfjordelva (1999), Henselva (2000), and Skorga (2003). Only in the outermost infected river in the region, the River Måna, has the 
parasite yet to be recovered following treatment. From Region 7 there were similar occurrences, first after rotenone treatment in 1993 and then again after treatment in 2002. Following both treatments the parasite was first recorded in the relatively large River Steinkjervassdraget 3 to $4 \mathrm{yr}$ post treatment, and then in the smaller River Figga later the same or following year. One likely explanation for this pattern of reinfection is that treatments have failed to eradicate the parasite in the largest rivers, these being the most complex to treat chemically, whereas the smaller rivers have been re-infected by infected fish migrating in the fjord systems (Hjeltnes et al. 2006). The present study is the first attempt to unify the influence of freshwater inflow and dispersal distance to model the probability of inter-river dispersal of G. salaris. The overall good fit of the model to data, and especially the strong association between infection status in rivers and freshwater inflow into the postulated dispersal pathways, lends new support to the hypothesis of inter-river dispersal of G. salaris through fjords. The predictive ability of the model with only freshwater inflow measured using AUC was 0.94, which compared to the AUC $=0.97$ of the full model supports the conclusion that freshwater inflow is a very strong predictor of the G. salaris infection status. Hence, it is evident that G. salaris can disperse and establish new populations on salmon stocks in adjacent rivers in fjord systems, but that such dispersal eventually will be prevented by a combination of low freshwater inflow and long distance between river outlets. It is also noteworthy that freshwater inflow typically was high in the inner fjords, where large rivers tend to drain into narrow fjord areas. The opposite applied to the outer fjord areas, these being more voluminous and where rivers tended to be smaller.

The dispersal pathways to secondary Gyrodactylus salaris-infected rivers in the present study have not been verified directly, but were postulated to be fjordwise from the nearest infected river. Therefore it is of interest to assess the dispersal pathways to rivers that deviate most strongly with regard to infection status versus model predictions. For the at-risk River Auneelva the predicted probability of G. salaris infection was 0.92. From this river there are records of totally 65 juvenile Atlantic salmon that have been examined for $G$. salaris infection in the national $G$. salaris surveillance program on 2 occasions in 2003 and 2004, with no detection of the parasite (Laboratory Management Information System, National Veterinary Institute, Norway). In view of the high prevalence of $G$. salaris normally found in infected rivers in Norway these samples indicate that the River Auneelva truly is non-infected, and then, as suggested by the present model, at high risk of acquiring G. salaris infection. The at-risk Rivers Strandaelva and Velledalselva in
Region 3, and Surna in Region 6, had predicted probabilities of 0.40 to 0.80 of infection. Infected rivers in these regions were treated with the pesticide rotenone in the late 1980s to early 1990s (Johnsen et al. 1999), and the parasite has not reappeared in these regions to date. This suggests that further dispersal of the parasite in these regions may have been prevented by the pesticide treatment.

The Rivers Hestdalselva in Region 8 and Korsbrekkelva in Region 3 had the lowest predicted probabilities ( 0.15 for both) of Gyrodactylus salaris infection among the secondary infected rivers, indicating that the postulated dispersal pathways for these rivers may be questioned. However, an interesting case is the River Sandeelva in Region 1, with a relatively low predicted probability $(0.39)$ of infection in the present study. The risk-assessment conducted by Høgåsen \& Brun (2003) concluded that the risk of inter-river dispersal of G. salaris on migrating fish from the River Drammenselva to the River Sandeelva was high, but that their analysis was sensitive to assumptions with regard to salinity in the fjord area covering the dispersal pathway. Incidentally, G. salaris was recorded in the River Sandeelva in 2003, 16 yr after G. salaris was recorded in the River Drammenselva. This is strong evidence that $G$. salaris is capable of dispersing over distances of $40 \mathrm{~km}$ through a fjord, given a sufficiently high amount of freshwater inflow into the fjord. The River Drammenselva was the largest river in the present study in terms of mean yearly freshwater drainage in the Regine database.

Neither the Atlantic salmon harvest in source rivers nor the time period at risk of Gyrodactylus salaris infection were significantly associated with infection status in rivers in the final logistic regression model. The lack of association of harvest category may reflect the fact that freshwater inflow and dispersal distance set the boundaries for inter-river dispersal, and that the number of infected fish migrating from a river plays a lesser role. Time-period at risk was unconditionally associated with infection status in rivers such that the categories for secondary infected rivers reflected longer periods at risk than for non-infected rivers at risk. Ideally, time dependency in the rate of inter-river dispersal should have been accounted for in the present model. However, it seems that the time of the first observation of G. salaris in the different rivers in Norway to a large extent reflects the intensity of surveillance activities, rather than the exact time of introduction. For example, G. salaris was recorded for the first time in 18 rivers during the period 1980-1981. This was due to intensified surveillance activity initiated by the 'Gyrodactylus committee' during 1980-1981 when more than 10000 juvenile Atlantic salmon from approximately 150 salmon rivers were examined for $G$. 
salaris infection (Johnsen \& Jensen 1986, Johnsen et al. 1999). The rate of inter-river dispersal of G. salaris may also have been influenced by rotenone treatments. For example, G. salaris was found on one fish in the River Leirelva (R8) in May 1996 (Johnsen et al. 1999). The River Leirelva was surveyed yearly for $G$. salaris and was rotenone treated about 1 mo after $G$. salaris was recorded to prevent further dispersal of the parasite (Johnsen et al. 1999). In the River Ranelva, G. salaris was not recorded in spite of relatively high freshwater inflow $\left(\log _{10}\right.$ freshwater inflow $\left.=-0.09\right)$ into a short dispersal pathway between these rivers $(0.4 \mathrm{~km})$. This indicates that the rotenone treatment initially prevented $G$. salaris dispersal between these rivers. However, in 2004 G. salaris re-appeared in the River Leirelva, and in 2006 the parasite was recorded for the first time in the River Ranelva. Overall, it seems that for short dispersal pathways with high inflow of freshwater, inter-river dispersal of G. salaris may be expected within a year or two. For relatively long dispersal pathways with lower inflow of freshwater, dispersal may take longer.

The present study has shown that a simple logistic regression model for inter-river dispersal of Gyrodactylus salaris can be used to predict the infection status of a river. From the 2-graph ROC curve (see Fig. 4B) it can be seen that there is a trade-off between false-positives and false-negatives in the classification which determines the optimal cut-off point for declaring infection present, since a high sensitivity will be associated with a low specificity and vice versa. The model can be used to map the risk of further dispersal of $G$. salaris (for example, in the event of the failed rotenone treatment of a river, or if the parasite is found in a new region) by calculating the freshwater inflow and dispersal distance for the rivers at risk. However, the cut-off point for reaction (i.e. the level of risk deemed crucial) depends on the cost of false negatives versus false positives.

To conclude, assuming a correct categorization of infected rivers into primary and secondary infected rivers, the origin of Gyrodactylus salaris in all but 2 out of 46 Norwegian rivers is adequately accounted for by the proposed dispersal model. The remaining 2 are the River Lærdalselva (R2) and River Beiarn (R10). Accordingly, we hypothesise that $G$. salaris has been disseminated in Norway via: (1) anthropogenic movement of infected salmon relating to stock enhancement and fish-farming practices, and (2) migration of infected salmon in fjord systems.

Acknowledgements. We thank T. Håstein and T. A. Mo for critical comments on the manuscript. We are also grateful to 3 anonymous referees for valuable comments and suggestions to improve this manuscript.

\section{LITERATURE CITED}

Anonymous (1999) Til laks åt alle kan ingen gjera? Norges offentlige utredninger, Vol 9. Statens forvaltningstjeneste, Oslo (English summary)

Appleby C, Mo TA (1997) Population dynamics of Gyrodactylus salaris (Monogenea) infecting Atlantic salmon, Salmo salar, parr in the river Batnfjordselva, Norway. J Parasitol 83:23-30

Bakke TA, Jansen PA, Hansen LP (1990) Differences in the host resistance of Atlantic salmon, Salmo salar L., stocks to the monogenean Gyrodactylus salaris Malmberg, 1957. J Fish Biol 37:577-587

Bakke TA, Harris PD, Jansen PA, Hansen LP (1992) Host specificity and dispersal strategy in gyrodactylid mongeneans, with particular reference to Gyrodactylus salaris (Platyhelminthes, Monogenea). Dis Aquat Org 13:63-74

Bakke TA, Harris PD, Cable J (2002) Host specificity dynamics: observations on gyrodactylid monogeneans. Int $\mathrm{J}$ Parasitol 32:281-308

Cable J, Harris PD, Bakke TA (2000) Population growth of Gyrodactylus salaris (Monogenea) on Norwegian and Baltic Atlantic salmon (Salmo salar) stocks. Parasitology 121:621-629

Finstad B, Økland F, Thorstad EB, Bjørn PA, McKinley RS (2005) Migration of hatchery-reared Atlantic salmon and wild anadromous brown trout post-smolts in a Norwegian fjord-system. J Fish Biol 66:86-96

Halvorsen O, Hartvigsen R (1989) A review of the biogeography and epidemiology of Gyrodactylus salaris. NINA Utred 2:1-41

Hansen H, Bachmann L, Bakke TA (2003) Mitochondrial DNA variation of Gyrodactylus spp. (Monogenea, Gyrodactylidae) populations infecting Atlantic salmon, grayling, and rainbow trout in Norway and Sweden. Int J Parasitol 33: $1471-1478$

Harris PD, Shinn AP, Cable J, Bakke TA (2004) Nominal species of the genus Gyrodactylus von Nordmann 1832 (Monogenea: Gyrodactylidae), with a list of principal host species. Syst Parasitol 59:1-27

Hjeltnes B, Mo TA, Jansen PA, Brabrand A, Johnsen BO, Stensli JH, Bakke TA (2006) Ny påvisning av Gyrodactylus salaris i Steinkjervassdraget og Figga I 2005: Mulige årsaker. Natl Vet Inst Rep 4:1-22

Høgåsen HR, Brun E (2003) Risk of inter-river transmission of Gyrodactylus salaris by migrating Atlantic salmon smolts, estimated by Monte Carlo simulation. Dis Aquat Org 57: 247-254

Jansen PA, Bakke TA (1991) Temperature-dependent reproduction and survival of Gyrodactylus salaris Malmberg, 1957 (Platyhelminthes: Monogenea) on Atlantic salmon (Salmo salar L.). Parasitology 102:167-173

Jansen PA, Bakke TA (1993) Regulatory processes in the monogenean Gyrodactylus salaris Malmberg-Atlantic salmon (Salmo salar L.) association. I. Field studies in southeastern Norway. Fish Res 17:87-101

Johnsen BO (1978) The effect of an attack by the parasite Gyrodactylus salaris on the population of salmon parr in the river Lakselva, Misvær in Northern Norway. Astarte 11:7-9

Johnsen BO, Jensen AJ (1985) Parasitten Gyrodactylus salaris på laksunger I norske vassdrag, Statusrapport. Direktoratet for vilt og ferskvannsfisk, Rapport 12:1-145

Johnsen BO, Jensen AJ (1986) Infestations of Atlantic salmon (Salmo salar) by Gyrodactylus salaris in Norwegian rivers. J Fish Biol 29:233-241

Johnsen BO, Jensen AJ (1991) The Gyrodactylus story in Norway. Aquaculture 98:289-302 
Johnsen BO, Møkkelgjerd PI, Jensen AJ (1999) Parasitten Gyrodactylus salaris på laks i norske vassdrag, statusrapport ved inngangen til år 2000. NINA Oppdragsmeld 617:1-129

Lund R, Heggberget TG (1992) Migration of Atlantic salmon, Salmo salar L., parr through a Norwegian fjord: potential infection path of Gyrodactylus salaris. Aquacult Fish Manage 23:367-372

Malmberg G (1988) Gyrodactylus salaris-infectioner, laxfisktransporter och odling i Norden. Vattenbruk 2:22-29

Mo TA, Nordheim K (2002) The surveillance and control programme for Gyrodactylus salaris in Atlantic salmon and rainbow trout in Norway. In: Fredriksen B, Mørk T (eds) Surveillance and control programmes for terrestrial and aquatic animals in Norway. Annual Report 2001. National Veterinary Institute, Oslo, p 155-159

Mo TA, Nordheim K (2003) The surveillance and control programme for Gyrodactylus salaris in Atlantic salmon and rainbow trout in Norway. In: Heier BT (ed) Surveillance and control programmes for terrestrial and aquatic animals in Norway. Annual Report 2002. National Veterinary Institute, Oslo, p 139-141

Mo TA, Nordheim K (2004) The surveillance and control programme for Gyrodactylus salaris in Atlantic salmon and rainbow trout in Norway. In: Mørk T, Hellberg H (eds) Surveillance and control programmes for terrestrial and aquatic animals in Norway. Annual Report 2003. National Veterinary Institute, Oslo, p 135-137

Mo TA, Nordheim K (2005) The surveillance and control programme for Gyrodactylus salaris in Atlantic salmon and rainbow trout in Norway. In: Mørk T, Hellberg H (eds) Surveillance and control programmes for terrestrial and aquatic animals in Norway. Annual Report 2004. National Veterinary Institute, Oslo, p 137-139

Mo TA, Nordheim K (2006) The surveillance and control programme for Gyrodactylus salaris in Atlantic salmon and rainbow trout in Norway. In: Brun E (ed) Surveillance and control programmes for terrestrial and aquatic animals in Norway. Annual Report 2004. National Veterinary Institute, Oslo, p 135-137

Olstad K, Cable J, Robertsen G, Bakke TA (2006) Unpredicted transmission strategy of Gyrodactylus salaris (Monogenea: Gyrodactylidae): survival and infectivity of parasites on dead hosts. Parasitology 133:33-41

Peeler EJ, Gardiner R, Thrush MA (2004) Qualitative risk assessment of routes of transmission of the exotic parasite Gyrodactylus salaris between river catchments in England and Wales. Prev Vet Med 64:175-189

Poleo ABS, Schjolden J, Hansen H, Bakke TA, Mo TA, Rosseland BO, Lydersen E (2004) The effect of various metals on Gyrodactylus salaris (Platyhelminthes, Monogenea) infections in Atlantic salmon (Salmo salar). Parasitology 128:169-177

Soleng A, Bakke TA (1997) Salinity tolerance of Gyrodactylus salaris (Platyhelminthes, Monogenea): laboratory studies. Can J Fish Aquat Sci 54:1837-1845

Soleng A, Bakke TA, Hansen LP (1998) Potential for dispersal of Gyrodactylus salaris (Platyhelminthes, Monogenea) by sea-running stages of Atlantic salmon (Salmo salar): field and laboratory studies. Can J Fish Aquat Sci 55: $507-514$

Soleng A, Jansen PA, Bakke TA (1999) Transmission of the monogenean Gyrodactylus salaris. Folia Parasitol 46: $176-184$

Appendix 1. Complete set of risk factors and model predictions (logistic regression) of the probability of Gyrodactylus salaris infection in rivers at risk (infection status $=0$ ) and secondary infected rivers (infection status $=1$ ) in the study. The table is sorted on infection status and predicted probabilities of infection (units for the risk factors are given in 'Materials and methods')

\begin{tabular}{|lccccccc|}
\hline River & Region & $\begin{array}{c}\text { Infection } \\
\text { status }\end{array}$ & $\begin{array}{c}\text { Salmon harvest } \\
\text { category }\end{array}$ & $\begin{array}{c}\text { Time at risk } \\
\text { category }\end{array}$ & $\begin{array}{c}\text { Dispersal } \\
\text { distance }\end{array}$ & $\begin{array}{c}\text { Freshwater } \\
\text { inflow }\end{array}$ & $\begin{array}{c}\text { Predicted prob- } \\
\text { ability of infection }\end{array}$ \\
\hline Storelva & R3 & 0 & 2 & 1 & 30.5 & -2.22 & 0.00 \\
Laksådalsvassdraget & R10 & 0 & 2 & 2 & 57.6 & -1.55 & 0.00 \\
Eira & R4 & 0 & 2 & 3 & 55.2 & -1.33 & 0.00 \\
Vasskordelva & R5 & 0 & 1 & 3 & 29.9 & -1.77 & 0.00 \\
Rotsundelva & R12 & 0 & 2 & 3 & 54.3 & -1.20 & 0.00 \\
Sagelva & $\mathrm{R} 5$ & 0 & 1 & 3 & 30.5 & -1.68 & 0.00 \\
Storelva & $\mathrm{R} 7$ & 0 & 1 & 1 & 20.1 & -1.89 & 0.01 \\
Orkla & $\mathrm{R} 7$ & 0 & 1 & 1 & 62.0 & -0.97 & 0.01 \\
Gaula & $\mathrm{R} 7$ & 0 & 1 & 1 & 59.0 & -1.02 & 0.01 \\
Sagelva & $\mathrm{R} 7$ & 0 & 1 & 1 & 18.8 & -1.85 & 0.01 \\
Tangstadelva & $\mathrm{R} 7$ & 0 & 2 & 3 & 50.8 & -1.16 & 0.01 \\
Visa & $\mathrm{R} 4$ & 0 & 2 & 31.4 & -1.35 & 0.01 \\
Osenvassdraget & $\mathrm{R} 4$ & 0 & 2 & 3 & 44.0 & -1.29 & 0.01 \\
Istadelva & $\mathrm{R} 4$ & 0 & 2 & 3 & 40.8 & -1.36 & 0.01 \\
Verdalsvassdraget & $\mathrm{R} 7$ & 0 & 2 & 3 & 54.3 & -0.99 & 0.01 \\
Futelv & $\mathrm{R} 11$ & 0 & 1 & 2 & 48.9 & -1.07 & 0.01 \\
Levangervassdraget & $\mathrm{R} 7$ & 0 & 2 & 3 & 47.7 & -1.09 & 0.01 \\
Askerelva & $\mathrm{R} 1$ & 0 & 1 & 2 & 56.9 & -0.85 & 0.01 \\
Ytredalselva & $\mathrm{R} 2$ & 0 & 2 & 1 & 48.0 & -1.02 & 0.01 \\
Oppdølselva & $\mathrm{R} 4$ & 0 & 2 & 3 & 33.2 & -1.28 & -1.10 \\
Dalaelvi & $\mathrm{R} 2$ & 0 & 2 & 1 & 41.0 & 0.02 \\
\hline
\end{tabular}


Appendix 1 (continued)

\begin{tabular}{|c|c|c|c|c|c|c|c|}
\hline River & Region & $\begin{array}{l}\text { Infection } \\
\text { status }\end{array}$ & $\begin{array}{c}\text { Salmon harvest } \\
\text { category }\end{array}$ & $\begin{array}{c}\text { Time at risk } \\
\text { category }\end{array}$ & $\begin{array}{c}\text { Dispersal } \\
\text { distance }\end{array}$ & $\begin{array}{c}\text { Freshwater } \\
\text { inflow }\end{array}$ & $\begin{array}{l}\text { Predicted prob- } \\
\text { ability of infection }\end{array}$ \\
\hline Årosvassdraget & $\mathrm{R} 1$ & 0 & 3 & 2 & 62.7 & -0.64 & 0.02 \\
\hline Tressa & $\mathrm{R} 4$ & 0 & 2 & 3 & 31.1 & -1.28 & 0.02 \\
\hline Storelva & R3 & 0 & 2 & 1 & 25.9 & -1.39 & 0.02 \\
\hline Valnesfjordvassdraget & R11 & 0 & 1 & 2 & 27.0 & -1.35 & 0.02 \\
\hline Valnesforsen & R10 & 0 & 2 & 2 & 36.8 & -1.09 & 0.03 \\
\hline Hareidvassdraget & R3 & 0 & 2 & 1 & 28.4 & -1.26 & 0.03 \\
\hline Mittetelva & $\mathrm{R} 4$ & 0 & 2 & 3 & 27.8 & -1.27 & 0.03 \\
\hline Flåmselvi & $\mathrm{R} 2$ & 0 & 3 & 1 & 57.5 & -0.63 & 0.03 \\
\hline Nærøydalselvi & $\mathrm{R} 2$ & 0 & 3 & 1 & 58.0 & -0.61 & 0.03 \\
\hline Saltdalselva & R11 & 0 & 1 & 2 & 43.2 & -0.89 & 0.04 \\
\hline Aurlandsvassdraget & $\mathrm{R} 2$ & 0 & 3 & 1 & 52.0 & -0.71 & 0.04 \\
\hline Mørkrisvassdraget & $\mathrm{R} 2$ & 0 & 3 & 1 & 52.6 & -0.65 & 0.04 \\
\hline Manndalselva & R12 & 0 & 2 & 3 & 33.4 & -1.05 & 0.04 \\
\hline Solnørelva & R3 & 0 & 2 & 1 & 15.1 & -1.42 & 0.05 \\
\hline Røa & $\mathrm{R} 4$ & 0 & 2 & 3 & 23.5 & -1.17 & 0.06 \\
\hline Årøyvassdraget & $\mathrm{R} 2$ & 0 & 3 & 1 & 46.4 & -0.64 & 0.07 \\
\hline Mossa & R7 & 0 & 2 & 3 & 36.2 & -0.85 & 0.07 \\
\hline Sogndalselvi & $\mathrm{R} 2$ & 0 & 3 & 1 & 40.1 & -0.76 & 0.08 \\
\hline Nidelvvassdraget & R7 & 0 & 1 & 1 & 29.6 & -0.95 & 0.09 \\
\hline Søуа & R6 & 0 & 1 & 1 & 17.2 & -1.12 & 0.12 \\
\hline Stjørdalsvassdraget & R7 & 0 & 1 & 1 & 21.1 & -0.99 & 0.14 \\
\hline Homla & R7 & 0 & 1 & 1 & 20.6 & -0.99 & 0.14 \\
\hline Silsvassdraget & R9 & 0 & 1 & 3 & 34.9 & -0.66 & 0.16 \\
\hline Mollelva & R7 & 0 & 2 & 3 & 26.9 & -0.80 & 0.17 \\
\hline Toåa & R6 & 0 & 1 & 1 & 28.4 & -0.73 & 0.20 \\
\hline Vagsvikelva & R3 & 0 & 2 & 1 & 22.4 & -0.77 & 0.25 \\
\hline Ørskogelva & R3 & 0 & 2 & 1 & 19.0 & -0.75 & 0.32 \\
\hline Stordalselva & R3 & 0 & 2 & 2 & 22.7 & -0.67 & 0.33 \\
\hline Surna & R6 & 0 & 2 & 1 & 19.4 & -0.67 & 0.40 \\
\hline Hølenelva & R1 & 0 & 1 & 2 & 28.7 & -0.44 & 0.42 \\
\hline Strandaelva & R3 & 0 & 2 & 2 & 13.3 & -0.58 & 0.60 \\
\hline Velledalselva & R3 & 0 & 1 & 1 & 5.2 & -0.49 & 0.80 \\
\hline Auneelva & R8 & 0 & 1 & 3 & 16.3 & 0.01 & 0.92 \\
\hline Hestdalselva & R8 & 1 & 1 & 3 & 38.1 & -0.61 & 0.15 \\
\hline Korsbrekkelva & R3 & 1 & 2 & 2 & 32.7 & -0.72 & 0.15 \\
\hline Signaldalselva & R12 & 1 & 2 & 3 & 20.8 & -0.88 & 0.20 \\
\hline Fættenelva & $\mathrm{R} 7$ & 1 & 1 & 1 & 2.7 & -1.23 & 0.22 \\
\hline Sandeelva & R1 & 1 & 3 & 2 & 38.7 & -0.26 & 0.39 \\
\hline Bardalselva & R9 & 1 & 1 & 3 & 25.3 & -0.33 & 0.60 \\
\hline Måna & R4 & 1 & 1 & 3 & 11.2 & -0.47 & 0.74 \\
\hline Innfjordelva & R4 & 1 & 2 & 3 & 9.9 & -0.45 & 0.77 \\
\hline Halsanelva & R8 & 1 & 1 & 3 & 0.9 & -0.64 & 0.77 \\
\hline Sannaelva & R9 & 1 & 2 & 3 & 20.7 & -0.11 & 0.84 \\
\hline Leirelva & R8 & 1 & 1 & 3 & 21.0 & -0.09 & 0.85 \\
\hline Aureelva & R3 & 1 & 1 & 1 & 2.2 & -0.38 & 0.89 \\
\hline Skorga & $\mathrm{R} 4$ & 1 & 3 & 3 & 2.1 & -0.34 & 0.90 \\
\hline Norddalsvassdraget & R3 & 1 & 2 & 2 & 5.0 & -0.26 & 0.91 \\
\hline Eidsdalselva & R3 & 1 & 2 & 2 & 3.2 & -0.30 & 0.91 \\
\hline Valldøla & R3 & 1 & 1 & 2 & 11.6 & -0.11 & 0.92 \\
\hline Usma & R5 & 1 & 3 & 3 & 11.4 & -0.02 & 0.94 \\
\hline Ranelva & R8 & 1 & 1 & 3 & 0.4 & -0.09 & 0.97 \\
\hline Rauma & $\mathrm{R} 4$ & 1 & 2 & 3 & 7.5 & 0.08 & 0.97 \\
\hline Sletterelva & R9 & 1 & 2 & 3 & 11.5 & 0.32 & 0.98 \\
\hline Hundåla & R8 & 1 & 2 & 3 & 9.1 & 0.33 & 0.99 \\
\hline Lundelva & $\mathrm{R} 7$ & 1 & 2 & 3 & 3.9 & 0.25 & 0.99 \\
\hline Drevja & $\mathrm{R} 8$ & 1 & 2 & 3 & 5.4 & 0.45 & 0.99 \\
\hline Bjerka & R9 & 1 & 2 & 3 & 5.3 & 0.65 & 1.00 \\
\hline Fusta & R8 & 1 & 3 & 3 & 8.5 & 0.95 & 1.00 \\
\hline Lierelva & R1 & 1 & 3 & 2 & 4.0 & 1.07 & 1.00 \\
\hline Litledalselva & R5 & 1 & 1 & 3 & 1.0 & 1.16 & 1.00 \\
\hline Steinkjervassdraget & R7 & 1 & 2 & 3 & 1.4 & 1.38 & 1.00 \\
\hline
\end{tabular}

